\title{
The Influence of Parents' Social Status and Economic Conditions on Social Studies Learning Achievement of Elementary School Students 25 Madello Soppeng regency
}

\author{
Andi Hardiyanti ${ }^{1)}$, Shermina Oruh ${ }^{2)}$, Andi Agustang ${ }^{3)}$ \\ ${ }^{1)}$ Student of Postgraduate Doctoral Degree in Sociology, Universitas Negeri Makassar, Indonesia \\ 2) Universitas Pejuang Republik Indonesia, Indonesia \\ 3) Universitas Negeri Makassar, Indonesia \\ Corresponding Author: Andi Hardiyanti, Email: ahardiyanti2@gmail.com
}

\begin{abstract}
History: Received 07/12/2021 | Revised 16/12/2021 | Accepted 19/01/2022 | Published 31/01/2022
Abstract. The economic role of parents, in general, can be said to have a positive relationship to increasing student learning achievement because students' teaching and learning process requires tools or a set of teaching or learning. The aims of this study are 1) to find out whether social status affects the social studies learning achievement of students at SD 25 Madello, Kabupaten Soppeng., 2) To find out whether the economic conditions of parents affect the social studies learning achievement of students at SD 25 Madello, Soppeng Regency., 3) To find out whether the social status and economic conditions of parents affect the social studies learning achievement of students at SD 25 Madello, Soppeng Regency. This research method uses quantitative expost facto research through a correlational approach. The sampling technique of this study is a probability technique with 43 students from grades III, IV, V. The results of this study and alternative hypothesis testing $(\mathrm{H} 3)$ there is a significant influence between social status and parents' economic condition on social studies learning achievements of elementary school students. 25 Madello, Soppeng Regency.
\end{abstract}

Keywords: Social Status; Economic Conditions; Learning Achievement

\begin{abstract}
Abstrak. Peranan ekonomi orang tua secara umum dapat dikatakan mempunyai hubungan yang positif terhadap peningkatan prestasi belajar peserta didik ini, disebabkan proses belajar mengajar peserta didik membutuhkan alat-alat atau seperangkat pengajaran atau pembelajaran. Tujuan dari penelitian ini yakni: 1) untuk menganalisis apakah status sosial berpengaruh terhadap prestasi belajar IPS peserta didik SD 25 Madello Kabupaten Soppeng., 2) Untuk mengetahui apakah kondisi ekonomi orang tua berpengaruh terhadap prestasi belajar IPS peserta didik SD 25 Madello Kabupaten Soppeng., 3) Untuk menganalisis apakah status sosial dan kondisi ekonomi orang tua berpengaruh terhadap prestasi belajar IPS peserta didik SD 25 Madello Kabupaten Soppeng. Metode penelitian ini menggunakan kuantitatif dengan jenis penelitian expost facto melalui pendekatan korelasional. Teknik sampling penelitian ini adalah teknik probality dengan subjek penelitian sejumlah 43 siswa dari kelas III, IV, V. Hasil dari penelitian ini dan pengujian hipotesis alternatif (H3) ada pengaruh yang signifikan antara status sosial dan kondisi ekonomi orangtua terhadap prestasi belajar IPS peserta didik SD 25 Madello Kabupaten Soppeng.
\end{abstract}

Kata kunci: Status Sosial; Kondisi Ekonomi; Prestasi Belajar. 


\section{INTRODUCTION}

Education is one of the foundations in educating the nation's children to build the nation and state into a developed country. It currently plays an important role as the basis for producing quality human beings who have competitiveness and the basic ability to absorb technology to increase productivity. According to (Abdullah and Safarina, 2013), "Education is one of the functions that must be carried out with the best of the family, community, and government in an integrated manner to develop the function of education". Starting from this awareness, it is necessary to plan policy steps and programs to create the human qualities needed following the demands of the times. In this context, all aspects of society must improve the nation's education. The purpose of national language education chapter II article 3 of the Republic of Indonesia Law no. 20 of 2003 concerning the national education system (2003: 5) are: "The development of the potential of students to become human beings who believe and fear God Almighty, have a noble character, are healthy, knowledgeable, capable, creative, independent, and become citizens who democratic and responsible. Therefore, Indonesian citizens have the power to get quality education in line with the interests and talents of the successors of this nation, regardless of social status, economic status, ethnicity, ethnicity, religion, and gender. In a learning phase, it will be said that the teaching- learning process is an activity that teachers usually carry out as learning resources and students as recipients of this learning. This is social interaction or introducing knowledge from teachers to students (Pratiwi \& Prasetya, 2019). Education is a conscious, planned, and systematic effort to humanize humans or learn the knowledge, skills, and habits of a group of people passed down from one generation to the next through teaching, training, or research. The definition of education, according to Dewey is the process of forming fundamental skills intellectually and emotionally towards nature and fellow human beings. In contrast to the notion of education, according to Dewantara, education is an effort to advance the development of character (inner strength), mind (intellect), and physical child. Education is a conscious and planned effort to create a learning atmosphere and learning process. Students actively develop their potential to have religious, spiritual strength, self-control, personality, intelligence, noble character, and skills needed by society, nation, and state.

To form quality successors of the nation, students need learning resources or teachers who have characteristics or characteristics, namely having an ideal personality following pedagogic and psychological requirements, as for what must be owned by educators, namely having the competence and having teacher professionalism.

In the teaching and learning process, should be able to realize an effective, efficient, 
and interesting learning process. Teachers or teachers should be able to provide appropriate teaching in terms of knowledge and student learning strategies to create a comfortable and efficient learning atmosphere both in and outside the classroom. Learning will be successful if students experience an increase in the learning that has been given and can solve the reflection questions that the teacher has given, the teacher or teacher has met many kinds of students, so teachers and students need to know and deepen learning theories in order to help solve students' learning problems. Law of the Republic of Indonesia no. 20 of 2003 concerning the National Education System Chapter II article 3 states that: National education aims to develop the potential of students to become human beings who believe and fear God Almighty, have a noble character, are healthy, knowledgeable, capable, creative, independent, and become democratic and responsible citizens.

Social studies subjects in elementary schools are an embodiment of an interdisciplinary approach. To form quality future generations, students need learning resources or teachers who have characteristics or characteristics, namely having an ideal personality following pedagogic and psychological requirements, as for what must be owned by educators, namely having the competence and having teacher professionalism.
In the teaching and learning process, should be able to realize an effective, efficient, and interesting learning process. Teachers or teachers should be able to provide appropriate teaching in terms of knowledge and student learning strategies to create a comfortable and efficient learning atmosphere both in and outside the classroom. Learning will be successful if students experience an increase in the learning given and can solve the reflection questions that the teacher or teacher has given. The teacher or teacher has met many kinds of students, so teachers and students need to know and deepen learning theories so that they can help solve the problems of learning for social science students, which emphasizes students interacting with each other, especially with friends and teachers, when learning activities are carried out. This can be seen from the rationalization of the design of social studies subjects which aim to develop the ability of students to become members of the community who have the knowledge, understanding, and analytical skills of the social conditions of society in entering dynamic social life, especially in the process of learning activities in the classroom. (Henri, 2018). (M. Dimyati and Mudjiono, 2013) stated that "Learning achievement is the result of an interaction between learning and teaching". (Femi Olivia, 2011) defines "Learning achievement is the peak of learning outcomes that can reflect the results of student learning success against the learning 
objectives that have been set." The Ministry of (National Education, 2006) aims explicitly for social studies subjects so that students have the following abilities: (1) develop concepts related to people's lives and their environment; (2) have the basic ability to think logically and critically, curiosity, problem-solving and skills in social life; (3) have a commitment and awareness of social and human values; and (4) have the ability to communicate, cooperate and have competence in a pluralistic society at local, national and global levels.

Based on the description above, it can be said that social studies subjects have strategic and essential value in preparing superior, reliable, and moral human resources from an early age. Social studies subjects are systematically, comprehensively, and integrated with the learning process towards maturity and success in social life. Once the importance of social studies in everyday life is inversely proportional to the response given by students in this subject (Minat et al., 2010). Related to education, to create quality and high-achieving human beings, students must have good learning achievements. Learning achievement is an important indicator to measure the success of the teaching and learning process, and learning achievement can also be a benchmark of the level of students' understanding of certain materials that have been given after students experience the learning process for a certain period of time and are expressed in the form of values.
Observations in the field found that the problem was that parents of students had a very limited economy. Hence, it wasn't easy to finance their children in taking a better education. Most of the parents of students had an education level that only graduated from elementary school and did not have an education bench, so they did not understand about levels of education that can take their children to a better future. If the child is not supported with adequate facilities for his educational needs, the child will have difficulty learning so that achievement is achieved. Breastfeeding for children will also be low due to inadequate parental income to support their children's schooling needs (Suciningrum \& Rahayu, 2015). The social environment is a community environment where there are individuals with each other. There will be many differences that distinguish one person from another in social life. Then these differences will form a level that will unintentionally become a differentiator in society. These differences can classify an individual to a level that unintentionally includes the individual into a certain level. This level cannot be requested or rejected because the difference occurs by itself and forms a level by itself. According to (Nasution, 2004), social status is a person's position in a social group. Social status (social status) is related to other people's social environment, prestige, rights, and obligations. Soekanto defines "status or position as a person's place 
or position in a social group with respect to other people in an even larger group.

Factors that significantly affect the teaching and learning process can be classified into two groups, namely internal factors, and external factors. Internal factors can be interpreted as factors from within the individual, as the main role as a subject of study, such as health, body normality, interests, character. Internal factors need attention for improving learning achievement. While external factors such as family and environmental factors. Family factors can be in the form of circumstances or economic conditions of parents or students' families. The socioeconomic status of their parents influences the consumption behavior of students. According to Wahyono, students' consumption behavior cannot be separated from the influence of their parent's socioeconomic status (Purwati, 2011).

(Ackadiyah, 2013)

Parents socioeconomic status is a person's place in general in society with respect to other people, in terms of environment, association, prestige, and rights and obligations (Soejono Soekanto, 2012). Parents' socioeconomic status and adequate learning facilities and infrastructure can help students provide direction and handle learning, which means that it can provide the strength contained in (Themselves 2011). Thus, students are expected to study hard and diligently to obtain good and satisfying learning achievements.
The economic role of parents, in general, can be said to have a positive relationship with increasing student learning achievement because the teaching and learning process requires students to use tools or a set of teaching or learning tools, where these tools are used to make it easier for students to get information, manage learning materials that can be used. Obtained from school. The economic situation of the parents of students also supports students in the procurement of learning facilities and infrastructure, which will facilitate and assist the school in improving the teaching and learning process. A set of teaching or learning requires no small amount of money. Teaching and learning tools mean textbooks, pencils, rulers, books, worksheets, etc.

This situation also occurs at SD 25 Madello, Soppeng Regency. This school accommodates students from various economic backgrounds and different parents. The socio-economic condition of parents is one factor that determines the success of children's education. The diversity of parents' financial backgrounds can also affect the ability to finance their children.

(Reni, 2014) states that: In general, children from upper-middle-class families get more direction and good guidance from their parents. Children with low economic backgrounds can get sufficient guidance and direction from their parents because parents focus more on meeting their daily needs. 
The socioeconomic conditions of the family certainly affect the development of children, especially their learning achievement. If we note that with a good economy, the material environment faced by children in the family is wider, students have wider opportunities to develop various skills. That students do not develop if there is no infrastructure. The relationship between his parents lives in a moderate socioeconomic status and is less subject to fundamental pressures such as obtaining an adequate living. (Megawati, 2021) Social stratification relates to an individual or group's status (position) with a set of roles that must be realized. Moore and Davis argue (Sunarto, 1993: 116) social stratification is necessary for the survival of a society that places a person in a high or low social position. Through social stratification, social order is possible in people's lives. In Weber's concept, various factors can influence and shape social stratification. Factor. Social stratification that determines the status of a person or group in society can be obtained based on the descent, which is not accompanied by an effort (ascribed status), for example, social status based on caste in India or Bali, but some can be obtained only by hard work (achieved status), for example, social status motivated by the possession of one's education level. Apart from Weber's opinion, further research will only focus on social status, motivated by economic factors (Sunarto, 1993).
Suppose the child lives in a low-income family. In that case, the child's basic needs are not met, resulting in inadequate learning facilities for students and less effective learning. Children's education is also disrupted. It may even be that children have to work to earn a living to help their parents even though it is not yet time for children to work. Things like this will also affect children's learning achievement in school. Although it is undeniable that the family's economy is weak, this situation has become a whip for him to study harder and eventually become a big success.

On the other hand, rich families often tend to spoil their children. Children will only have fun and splurge, so as a result, children are less able to focus their attention on learning. This can also interfere with children's education so that their learning achievement is not satisfactory.

(Ahmadi, 2016) explains that: The school as an educational center seeks to help increase the growth and development of students. However, the success of the teaching and learning process is influenced by several factors, both from within the students and from the child's environment.

In connection with the explanation above, it is necessary to have a breakthrough in identifying the factors that can affect the improvement of teaching quality in general and the improvement of students' social studies learning achievement in particular by 
utilizing all learning resources in the teaching process. These learning resources are learning situations and environments, teaching tools, and materials. These learning resources must be optimized in the teaching and learning process. Based on this background, the authors are interested in researching: "The Influence of Parents' Social Status and Economic Conditions on Social Studies Learning Achievement of Students at SD 25 Madello, Soppeng Regency".

Based on the background above, the formulation of the problem is as follows: 1) Does social status affect the social studies learning achievement of SD 25 Madello elementary school students, Soppeng Regency?, 2) Does the economic condition of parents affect the social studies learning achievement of elementary school students 25 Madello, Soppeng Regency?., 3) Do the social status and economic conditions of the parents affect the social studies learning achievement of the 25 Madello elementary school students, Soppeng Regency?

\section{RESEARCH METHODS}

The approach used in this research was quantitative. The type of research used is expost facto with a correlational approach, namely analysis to determine the effect of two or more variables (Purnomo \& Rosalina, 2016). According to (Sugiyono, 2011), "quantitative methods are used to examine certain populations or samples, sampling techniques were generally carried out randomly, data collection used quantitative/statistical data analysis research instruments with the aim of testing hypotheses. determined" This study seeks to reveal the effect of the variables between social status and the economic condition of parents on the social studies learning achievement of students at SD 25 Madello, Soppeng Regency. The population in this study were all students in grades III, IV, and V of SD 25 Madello, Soppeng Regency, which collected 106 students. The sampling technique used in this study was a probability or placement technique, where the research sample was 43 students in grades III, IV, and V SD 25 Madello, Soppeng Regency. Management of research data, carried out using the Statistical Package for Social Science (SPSS) application for windows version 20. Using inferential statistical analysis including a) linearity test, b) multicollinearity test, c) correlation analysis, d) simple linear regression analysis, e) Multiple linear regression analysis, f) Statistical Hypothesis.

\section{DISCUSSION}

The results of descriptive statistical data analysis of variables of social status and economic conditions of parents on social studies learning achievement of students at SD 25 Madello, Soppeng Regency. The results of descriptive analysis on the social status variables of parents in class III are in the high category with a percentage of $62 \%$, class IV is 
in the high category with a percentage of $53 \%$, and class $\mathrm{V}$ is in the high category with a percentage of $73 \%$. While the results of the descriptive analysis on the variable of the economic condition of parents in class III are at a high level with a percentage of 54\%, class IV is at a high level with a percentage of $47 \%$ and class $\mathrm{V}$ is at a level with a percentage of $80 \%$. Furthermore, the results of descriptive analysis on the social studies learning achievement variable in class III are at a good level with a percentage of $85 \%$, class IV is in a good category with a percentage of $67 \%$, and class $\mathrm{V}$ is in a good category with a percentage of $67 \%$. Parents' high social status and economic conditions significantly affect social studies learning achievement, which can be proven through inferential tests.

The results of data processing explain that hypothesis $\mathrm{HO}$ is rejected because the significant value is less than 0.05 , which means that $\mathrm{H} 1$ is accepted with the assumption that the social status and economic conditions of parents influence social studies learning achievement. This also indicates that if the influence of parents' social status and economic conditions increases, the social studies learning achievement of students at SD 25 Madello, Soppeng Regency will also increase. The regression equation also implies that every oneunit increase in the influence of parents' social status and parents' economic conditions will be followed by an increase in social studies learning achievement.
However, suppose the socioeconomic status of parents ensures the welfare of their children. In that case, if the parents do not pay special attention to their children's education, it will also affect the social development of their children. The statement above can be interpreted that parents who have aboveaverage incomes are sometimes more concerned with their work and social conditions in the community. Sometimes, they focus less on their children even though they can financially meet their children's basic needs in terms of education. Meanwhile, there are families whose socioeconomic status is middle to lower but places great importance on good and adequate education for their children to improve their social position. Research conducted by Dini stated that the factors that influence interest in continuing education to higher education are learning motivation factors, learning achievement factors, and parents' socioeconomic conditions (Barokah \& Yulianto, 2019). The social position will affect the person's position in different social groups. According to (Ngalim Purwanto, 2017) suggests that: The family's financial ability will directly or indirectly influence education and work or position and consider the results achieved in education and career.

In addition, harmonious family conditions will lead to student learning success because all family functions are realized. Meanwhile, less harmonious family conditions do not support student learning success 
because one of the family functions is not realized. Parental attention to children influences the smoothness of children's education at school. The needs of children in families from groups with high socioeconomic status tend to be considered compared to children from groups with low socioeconomic status.

The significance value for the influence of the variables of social status and parents' economic conditions simultaneously on social studies learning achievement in class III is $\mathrm{Sig}$ $0.000<0.05$ and $\mathrm{F}$ count is $27,293>\mathrm{F}$ table 3.98, class IV is Sig $0.000<0.05$ and F count is $17.465>$ F table 3.81 and class V Sig 0.000 $<0.05$ and $F$ count 21.672 $>F$ table 3.81. So it can be concluded that the third hypothesis testing (H3) in class III, IV, and V are accepted, which means that social status and parents' economic condition simultaneously influence social studies learning achievement. This is in line with the descriptive analysis, which provides information on the influence of social status and economic conditions of parents who are in the high category, followed by social studies learning achievement, which is in the very high category.

In addition, harmonious family conditions will lead to student learning success because all family functions are realized. Meanwhile, less harmonious family conditions do not support student learning success because one of the family functions is not realized. Parental attention to children influences the smoothness of children's education at school. The needs of children in families from groups with high socioeconomic status tend to be considered compared to children from groups with low socioeconomic status.

The significance value for the influence of the variables of social status and parents' economic conditions simultaneously on social studies learning achievement in class III is Sig $0.000<0.05$ and $\mathrm{F}$ count is $27,293>\mathrm{F}$ table 3.98, class IV is Sig $0.000<0.05$ and F count is $17.465>\mathrm{F}$ table 3.81 and class V Sig 0.000 $<0.05$ and $\mathrm{F}$ count 21.672 > F table 3.81. So it can be concluded that the third hypothesis testing (H3) in class III, IV, and V are accepted, which means that social status and parents' economic condition simultaneously influence social studies learning achievement. This is in line with the descriptive analysis, which provides information on the influence of social status and economic The higher the influence of the social status and economic conditions of parents, the better the social studies learning achievement of students and conversely, the lower the level of influence of the social status and economic conditions of parents, the less good the social studies learning achievement of students. The social status and economic conditions of parents certainly affect the development of students, namely with an adequate economy, the material environment faced by students in their families is wider, students have wider opportunities to develop 
various skills that students cannot develop if there is no infrastructure. As well as, the relationship of parents in social status and economic conditions are sufficient and are less subject to fundamental pressures such as in obtaining a good living. Parents can devote deeper attention to their children's future if they are not burdened with the problems of the primary needs of life. The high influence of parents' social status and economic conditions makes these students more motivated to maximize their potential in the learning process at school because they have the support of their parents. These students are also more controlled in terms of associations that can affect their learning achievement at school.

Based on the description above, it can be concluded that the influence of parents' social status and economic conditions is closely related to students' social studies learning achievement at SD 25 Madello, Soppeng Regency. As for some of the results of previous research conducted by (Hamran, 2016), the Effect of Parents' Social and Economic Status on the Motivation to Continuing Education to Higher Education in Class XII Students of SMK Negeri 1 Palangga, Gowa Regency. The research results conducted by (Irma Suriyani, 2012) showed the effect of parents' education level and parental income on student learning achievement at Bulo-bulo Elementary School, Arungkeke, Jeneponto Regency.

\section{CONCLUSION}

Based on the results of the analysis of hypothesis testing and discussions that have been carried out previously, the conclusions generated in this study are as follows: 1) The effect of social status on social studies learning achievement for students in grades III, IV, and V SD 25 Madello, Soppeng Regency is positive, which means the effect is positive. Significant, and the contribution is real.

\section{REFERENCES}

[1] Abdulsyani. (2014). Sosiologi Sistematika, Teori dan Terapan. Jakarta: Bumi Aksara.

[2] Ahmadi, Abu. (2016). Ilmu Sosial Dasar. Jakarta. Salemba Empat.

[3] Andarias, Simanjutak. (2016). Pendapatan Perkapita Nasional. Jakarta: FE Universitas Indonesia.

[4] Agustang, A., \& Sahabuddin, J. (2020, October). Model kolaborasi sosial pendidikan karakter di sekolah swasta kecamatan bissappu kabupaten bantaeng. In prosiding seminar dan diskusi pendidikan dasar.

[5] Agustang, A., Suardi, S., Putra, A. D. M., \& Oruh, S. (2021). Pemberdayaan Guru Mata Pelajaran Sosiologi Melalui Literasi Digital Berbasis Quick Response Code di Kecamatan Bissappu Kabupaten Bantaeng. Abdi: Jurnal Pengabdian dan Pemberdayaan Masyarakat, 3(2), 175-188.

[6] Ackadiyah, S. (2013). Pengaruh Status Sosial Ekonomi Orang Tua Terhadap Motivasi Belajar Siswa Sma Negeri 2 Purworejo. Oikonomia: Jurnal Pendidikan Ekonomi, 2(4), 3-6.

[7] Depdiknas. (2006). Standar Kompetensi dan Kompetensi Dasar Tingkat SD/MI. Jakarta: BNSP.

[8] Barokah, N., \& Yulianto, A. (2019). Pengaruh Lingkungan Sekolah, Self Efficacy, dan Status Sosial Ekonomi Orang Tua terhadap Minat Melanjutkan Pendidikan 
Tinggi Dengan Prestasi Belajar Sebagai Variabel Mediasi. Jurnal Pendidikan Dan Ekonomi, $\quad 8(2), \quad 434-452$. https://doi.org/10.15294/eeaj.v8i2.31498

[9] Henri. (2018). 済無No Title No Title No Title. Angewandte Chemie International Edition, 6(11), 951-952., 3.

[10] Megawati, A. (2021). Pengaruh Status Ekonomi Orang Tua dan Sosialisasi Dalam Keluarga Terhadap Prestasi Belajar. 7(3), 1154-1162.

https://doi.org/10.31949/educatio.v7i3.1374

[11] Minat, P., Dan, B., Sosial, S., Keluarga, E., Belajar, P., Pada, S., Pelajaran, M., Akuntansi, E., Xi, K., Pengetahuan, I., Sma, S., \& Pekanbaru, A. (2010). Jurnal Photon Vol. 1 No.1, Oktober 2010. 1(1), 37-42.

[12] Pratiwi, D. E., \& Prasetya, N. E. (2019). Pengaruh Status Sosial Ekonomi Dan Motivasi Belajar Terhadap Prestasi Belajar Siswa Kelas V Sdn Tambaksari I Surabaya. JPPGuseda | Jurnal Pendidikan \& Pengajaran Guru Sekolah Dasar, 2(1), 3640. https://doi.org/10.33751/jppguseda.v2i1.993

[13] Purnomo, B., \& Rosalina, A. (2016). Pengaruh Status Sosial Ekonomi Orang Tua Terhadap Prestasi Belajar Siswa Kelas IVB SD NO 64/1 Muara Bulian. Jurnal Gentala Pendidikan Dasar, 1(2), 275-297. https://doi.org/10.22437/gentala.v1i2.7120

[14] Purwati, A. (2011). Pengaruh Status Sosial Ekonomi Orang Tua , Persepsi atas Lingkungan, dan Prestasi Belajar Ekonomi. Jurnal Ekonomi Bisnis, 16(1), 11-16.

[15] Suciningrum, N. P., \& Rahayu, E. S. (2015). Pengaruh Status Sosial Ekonomi Orang Tua Dan Motivasi Belajar Tehadap Minat Melanjutkan Studi Ke Perguruan Tinggi Pada Kelas Xi Di Sma Pusaka 1 Jakarta. Jurnal Pendidikan Ekonomi Dan Bisnis (JPEB), 3(1), 1. https://doi.org/10.21009/jpeb.003.1.1

[16] Suardi, S., Agustang, A., \& Jumadi, J. (2021). Dominasi Sekolah Negeri Terhadap Sekolah Swasta Sebagai Penyebab Kekerasan Simbolik Terhadap Siswa Sekolah Swasta. Jurnal Ilmiah Muqoddimah: Jurnal
Ilmu Sosial, Politik dan Hummanioramaniora, 5(2). 